\title{
Neopterin: A potential marker in chronic peripheral arterial disease
}

\author{
SALVATORE SANTO SIGNORELLI ${ }^{1}$, MASSIMILIANO ANZALDI ${ }^{1}$, VALERIO FIORE ${ }^{1}$, SAVERIO CANDIDO $^{2}$, \\ ROBERTO DI MARCO ${ }^{2}$, KATIA MANGANO ${ }^{2}$, CINZIA QUATTROCCHI $^{2}$ and SERGIO NERI $^{3}$ \\ ${ }^{1}$ Department of Medical and Pediatric Science, Section of Internal and Vascular Medicine; \\ Departments of ${ }^{2}$ Bio-Medical Sciences and ${ }^{3}$ Medical and Pediatric Science, \\ Section of Internal Medicine, University of Catania, Catania I-95125, Italy
}

Received February 25, 2013; Accepted March 5, 2013

DOI: $10.3892 / \mathrm{mmr} .2013 .1407$

\begin{abstract}
Neopterin is a marker of macrophage activation that has exhibited high plasma levels in atherosclerotic diseases including coronary heart disease and critical limb ischemia. The role of neopterin in chronic peripheral arterial disease (PAD) has yet to be elucidated. In the present study, neopterin (N) serum concentrations were analyzed in asymptomatic (AsP) and symptomatic (SyP) patients with PAD as well as controls (C). In total 120 subjects, 40 AsP [ankle brachial index $(\mathrm{ABI}) \leq 0.90], 40 \mathrm{SyP}(\mathrm{ABI} \leq 0.90$ plus pain in legs) and 40 controls $(\mathrm{ABI}>0.9)$ were enrolled. The results of the present study showed that neopterin plasma levels were statistically different among the groups. These findings demonstrated that activation of $\mathrm{N}$-mediated monocyte-macrophage, was also observed in chronic PAD.
\end{abstract}

\section{Introduction}

Inflammation plays a key role in the atherosclerotic process (1-4) and experimental studies have shown the crucial role played by markers of the acute phase reaction, such as C-reactive protein (5,6), serum amyloid A (7-10) and fibrinogen in the atherosclerotic process. Activation of macrophages is a marker of chronic latent inflammation of the arterial wall, most likely as a result of the interaction between macrophages and oxidized lipoproteins. Activated macrophages are the principal source of proinflammatory cytokines such as IL-1 $\beta$ and TNF- $\alpha$, and they contribute to the progression and instability of atherosclerotic plaques (12-14). Neopterin (N) is derived by specific monocyte-derived cells including macrophage-dendritic cells, and is considered to be a repre-

Correspondence to: Professor Salvatore Santo Signorelli, Department of Medical and Pediatric Science, University of Catania, Piazza Santa Maria di Gesù 7, Catania I-95125, Italy

E-mail: ssignore@unict.it

Key words: peripheral arterial disease, neopterin, macrophages, atherosclerosis sentative activation marker of macrophages on the stimulation of interferon $\gamma$ (15). Elevated plasma levels of $\mathrm{N}$ were found in patients with coronary artery diseases including stable ischemic heart disease and acute coronary syndrome (16-18), and it was associated with the progression of coronary heart disease (19). $\mathrm{N}$ is considered an independent predictor of heart failure (19). However, a limited number of studies have focused on $\mathrm{N}$ in severe peripheral arterial disease (PAD) such as critical limb ischemia (21), whereas no study has focused on chronic PAD. PAD is considered a marker of the extent of the atheromatous process and it is known that PAD patients have a high risk of mortality for ischemic events (22-25). The present study focused on $\mathrm{N}$ plasma levels in symptomatic (SyP) and asymptomatic (AsP) PAD patients and compared them to the controls.

\section{Materials and methods}

Patients characteristics. In total, 120 subjects, attending an outpatient clinic of vascular medicine, were grouped as follows: 40 were SyP PAD patients, 40 were AsP patients and 40 were control subjects (C). Syp and AsP, as well as C patients were carefully selected to obtain a similar distribution of the main clinical parameters between the groups in order to reduce the impact of certain factors, such as diabetes, use of statins and smoking, on the serum concentrations of $\mathrm{N}$ (Table I). To diagnose PAD, the ankle brachial index (ABI) was taken as $\leq 0.9$ and patients that complained of pain in the lower limbs when walking were considered Syp. Patients with ABI of $\leq 0.9$ without experience of pain when walking were considered AsP. Subjects with an ABI measurement $>0.9$ and pain-free in the lower limbs were considered $C$. The mean value of $\mathrm{ABI}$ was $0.70 \pm 0.9,0.80 \pm 0.6$ and $1.12 \pm 0.4$ in $\mathrm{SyP}, \mathrm{AsP}$ and $\mathrm{C}$, respectively.

Blood measurements. Venous blood samples were obtained from the patients within $12 \mathrm{~h}$ of fasting. A Neopterin Elisa kit for quantitative determination (IBL, Hamburg, Germany), as previously described by Westermann et al (26) and Smith et al (27), was used to measure the $\mathrm{N}$ concentrations. $\mathrm{N}$ values were expressed as nmol/litre (nmol/l). The within-coefficient of variability was $<3 \%$ in the $7.5 \mathrm{nmol} / 1 \mathrm{range}$. 
Table I. Clinical parameters of PAD patients (SyP, AsP and C).

\begin{tabular}{lcrr}
\hline Parameter & Sy PAD & As PAD & C \\
\hline Gender & $32 \mathrm{M} / 8 \mathrm{~F}$ & $31 \mathrm{M} / 9 \mathrm{~F}$ & $29 \mathrm{M} / 11 \mathrm{~F}$ \\
Age & $66 \pm 7.1$ & $64.5 \pm 8.3$ & $65.3 \pm 7.2$ \\
Hypertension & $62.5 \%(\mathrm{n}=25)$ & $52.5 \%(\mathrm{n}=21)$ & $55 \%(\mathrm{n}=22)$ \\
Diabetes & $75 \%(\mathrm{n}=30)$ & $70 \%(\mathrm{n}=28)$ & $70 \%(\mathrm{n}=28)$ \\
Dyslipidemia & $50 \%(\mathrm{n}=20)$ & $45 \%(\mathrm{n}=18)$ & $42.5 \%(\mathrm{n}=17)$ \\
Statins & $40 \%(\mathrm{n}=16)$ & $35 \%(\mathrm{n}=14)$ & $35 \%(\mathrm{n}=14)$ \\
Smoking & $37.5 \%(\mathrm{n}=15)$ & $42.5 \%(\mathrm{n}=17)$ & $35 \%(\mathrm{n}=14)$ \\
\end{tabular}

PAD, peripheral arterial disease; SyP, symptomatic; AsP, asymptomatic; C, controls.

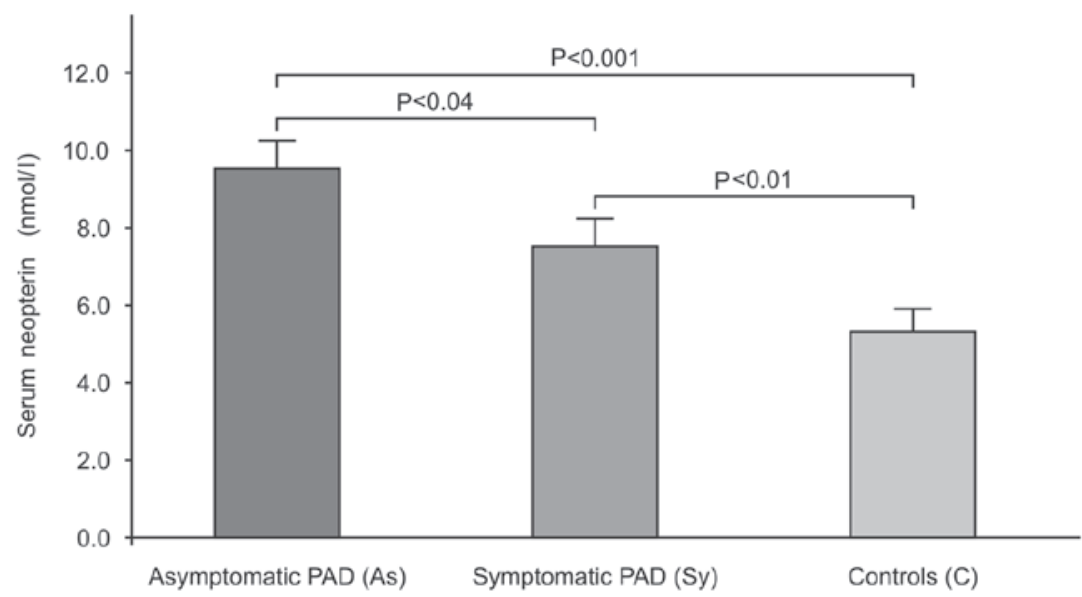

Figure 1. Mean value of neopterin $(\mathrm{N})$ and standard deviation in asymptomatic (AsP) and symptomatic (SyP) patients, as well as controls (C).

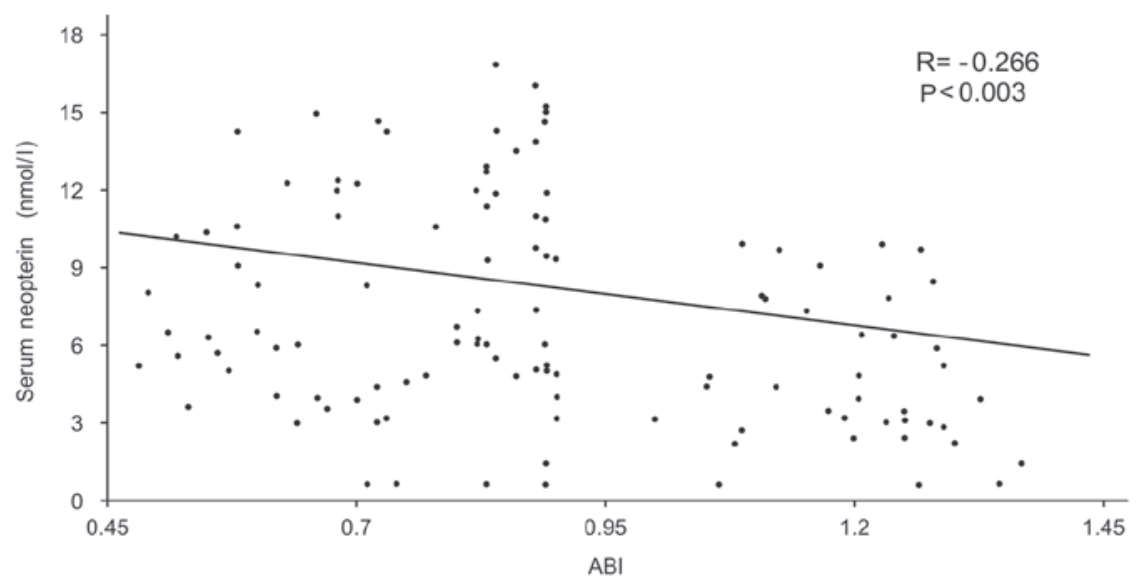

Figure 2. Inverse correlation observed between the ABI values and neopterin $(\mathrm{N})$ concentration.

Statistical analysis. The results are expressed as the means \pm standard deviation (SD). The statistical analysis was performed using the ANOVA test and the Student's t-test to compare the values (mean $\pm \mathrm{SD}$ ) identified in the three groups. A correlation between the $\mathrm{N}$ and ABI values in patients with PAD was assessed by using the Pearson's Chi-Square test or Fisher's exact test for categorical variables. A computerized statistical package (SPSS 10.1) for Windows was used. $\mathrm{P}<0.05$ was considered to indicate a statistically significant difference.

\section{Results}

Mean plasma levels were higher in SyP $(9.4 \pm 4.6 \mathrm{nmol} / \mathrm{l})$ and AsP (7.4 $\pm 4.0 \mathrm{nmol} / \mathrm{l})$ patients as compared to $\mathrm{C}$ patients 
$(5.3 \pm 3.2 \mathrm{nmol} / \mathrm{l})$ (Fig. 1). Patients of the statistical analysis based on the ANOVA test demonstrated significant differences in $\mathrm{N}$ levels between the groups $(\mathrm{P}<0.0001)$. Moreover, an inverse correlation (Fig. 2) between the ABI values and the $\mathrm{N}$ concentration $(\mathrm{r}=-0.266, \mathrm{P}<0.003)$ was observed.

\section{Discussion}

$\mathrm{N}$ is now considered a marker of macrophage activity in atherosclerosis. High serum levels of $\mathrm{N}$ were found in patients with chronic cardiac and coronary artery as well as acute coronary syndrome. A close correlation was observed between serum $\mathrm{N}$ concentration and angiographic evidence of multiple stenoses of coronary arteries in patients with stable angina (27). $\mathrm{N}$ is also considered a biomarker for atherosclerotic plaque instability both in coronary and carotid arteries (28). This biological product released from activated macrophages acts as a pro-oxidant $(29,30)$. Consequently, $\mathrm{N}$ is crucial in the inflammatory process and pathophysiology of the atheromatous process as well as in cell death (28). Concerning the peripheral arterial disorders, previously published data focused mainly on the high level of $\mathrm{N}$ in command-line interface (CLI) (20) and as previously reported (31) patients suffering from CLI have a poor diagnosis with regard to cardiovascular mortality. Those findings noted in the ischemic patients must be considered as relevant proof of the crucial pathophysiologic role played by the activated monocyte-macrophage.

The present study has focused on the effective role played by $\mathrm{N}$ in chronic AsP and SyP patients and the results showed higher blood concentrations of this marker compared to the $\mathrm{C}$ group. Our results must be considered useful in highlighting the activated process of macrophage cells involved both in severe or progressive stages of PAD as CLI, however, these cells are also deeply involved in chronic and stable PAD. Thus, we hypothesize that $\mathrm{N}$ is useful in identifying the activated process of macrophage cells in patients with chronic PAD. It is known that different biomarkers of inflammation, such as interleukins or metalloproteinases are elevated both in chronic and more severe PAD patients (32-38). Results of this study have shown the involvement of activated macrophages in chronic arterial disease of the lower limbs, albeit not symptomatic. This result may be associated with increased oxidative stress caused by chronic low blood perfusion. Furthermore, the inverse correlation between ABI values and levels of $\mathrm{N}$ demonstrates that there is a close association between the relative tissue ischemia as demonstrated by a lowered $\mathrm{ABI}$ value with the inflammatory process as marked by a higher plasma level of N. PAD patients suffer from relative ischemia as demonstrated by muscular effort when walking (e.g., intermittent claudication). Thus, a characteristic inflammatory pathway is present in the atherosclerotic diseases of coronary arteries and carotids, and of peripheral arteries (PAD).

In conclusion, neopterin is representative of the macrophage activation process and based on our findings, we hypothesize that the plasma level of $\mathrm{N}$ is useful to elicit the involvement of the activated macrophage, which, in turn, is able to promote oxidative stress. The plasma level of $\mathrm{N}$ may also be considered a new and diverse target for medical and interventional procedures in PAD patients. Therefore, new and original medical protocols are required to address this issue in order to protect against the inflammatory process, with $\mathrm{N}$ serving as a novel marker to monitor its efficacy.

\section{References}

1. Ross R: The pathogenesis of atherosclerosis: a prospective for the 1990s. Nature 362: 801-809, 1993.

2. Libby P, Sukhova G, Lee RT and Galis ZS: Cytokines regulate vascular functions related to stability of the atherosclerotic plaque. J Cardiovasc Pharmacol 25: S9-S12, 1995.

3. Jacobs M, van Greevenbroek MM, van der Kallen CJ, Ferreira I, Blaak EE, Feskens EJ, Jansen EH, Schalkwijk CG and Stehouwer CD: Low-grade inflammation can partly explain the association between the metabolic syndrome and either coronary artery disease or severity of peripheral arterial disease: the CODAM study. Eur J Clin Invest 39: 437-444, 2009.

4. Jenny NS, Yanez ND, Psaty BM, Kuller LH, Hirsh CH and Tracy RP: Inflammation biomarkers and near-term death in older man. Am J Epidemiol 165: 684-695, 2007.

5. Yu H and Rifai N: High-sensitivity C-reactive protein and atherosclerosis: from theory to therapy. Clin Biochem 33: 601-610, 2000.

6. Rifai N and Ridker PM: High-sensitivity C-reactive protein: a novel and promising marker of coronary heart disease. Clin Chem 47: 403-411, 2001.

7. Jenny NS, Arnold AM, Kuller LH, Tracy RP and Psaty BM: Serum amyloid $\mathrm{P}$ and cardiovascular disease in older men and women. Results from the cardiovascular health study. Arterioscler Thromb Vasc Biol 27: 352-358, 2007.

8. Yang RZ, Lee MJ, Hu H, Pollin TI, Ryan AS, Nicklas BJ, Snitker S, Horenstein RB, Hull K, Goldberg NH, Goldberg AP, Shuldiner AR, Fried SK and Gong DW: Acute-phase serum amyloid A: an inflammatory adipokine and potential link between obesity and its metabolic complications. PloS Med 3: e287, 2006

9. O'Brien KD and Chait A: Serum amyloid A: the 'other' inflammatory protein. Curr Atheroscler Rep 8: 62-68, 2006.

10. O'Brien KD, McDonald TO, Kunjathoor V, Eng K, Lewig K, Lopez R, Kirk EA, Chait A, Wight IN, de Beer FC and Le Boeuf BC: Serum amyloid A and lipoprotein retention in murine models of atherosclerosis. Arterioscler Thromb Vasc Biol 25: 785-790, 2005.

11. Unlu Y, Karapolat S, Karaca Y and Kiziltunc A: Comparison of levels of inflammatory markers and haemostatic factors in the patients with and without peripheral arterial disease. Thromb Res 117: 357-364, 2006.

12. Flugelman MY, Virmani R, Correa R, Yu ZX, Farb A, Leon MB, Elami A, Fu YM, Casscells W and Epstein SE: Smooth muscle cells abundance and fibroblast growth factors in coronary lesions of patients with nonfatal unstable angina. A clue to the mechanism of transformation from the stable to unstable state. Circulation 88: 2493-2500, 1993.

13. Tzoulaki I, Murray GD, Lee AJ, Rumley A, Lowe GD and Fowkes FG: C-reactive protein, interleukin-6, and soluble adhesion molecules as predictors of progressive peripheral atherosclerosis in the general population: Edinburgh Artery Study. Circulation 112: 976-983, 2005.

14. McDermott MM, Guralnik JM, Corsi A, Albay M, Macchi C, Bandinelli S and Ferrucci L: Patterns of inflammation associated with peripheral arterial disease: the InCHIANTI study. Am Heart J 150: 276-281, 2005.

15. Huber C, Batchelor JR, Fuchs D, Hausen A, Lang A, Niederwieser D, Reibnegger G, Swettly P, Troppmair J and Wacther H: Immune response-associated production of neopterin. Release from macrophages primarily under control of interferon-gamma. J Exp Med 160: 310-316, 1984.

16. Gupta S, Fredericks S, Scwartzman WA, Hot DW and Kaski JC: Serum neopterin in acute coronary syndrome. Lancet 349: 1252-1253, 1997.

17. Avanzas P, Domínguez-Rodríguez A, Arroyo-Espliguero R and Kaski JC: Neopterin and coronary artery disease. J Cardiol 54: 344-345, 2009.

18. Fuchs D, Avanzas P, Arroyo-Espliguero R, Jenny M, Consuegra-Sanchez L and Kaski JC: The role of neopterin in atherogenesis and cardiovascular risk assessment. Curr Med Chem 16: 4644-4653, 2009. 
19. Nazer B, Ray KK, Sloan S, Scirica B, Morrow DA, Cannon CP and Braunwald E: Prognostic utility of neopterin and risk of heart failure hospitalization after an acute coronary syndrome. Eur Heart J 32: 1390-1397, 2011.

20. Martin M, Gottsäter A, Nilsson PM, Mollnes TE, Lindblad B and Blom AM: Complement activation and plasma levels of C4b-binding protein in critical limb ischemia patients. J Vasc Surg 50: 100-106, 2009.

21. van Haelst PL, Liem A, van Boven AJ, Veegre NJ, van Veldhuisen DJ, Tervaert JW, Gans RO and Zijlstra F: Usefulness of elevated neopterin and C-reactive protein levels in predicting cardiovascular events in patients with non-Q-wave myocardial infarction. Am J Cardiol 92: 1201-1203, 2003.

22. Fowkes FG: Epidemiology of atherosclerotic arterial disease of the lower limbs. Eur J Vasc Surg 2: 283-291, 1988.

23. Aronow WS and Ahn C: Prevalence of coexistence of coronary artery disease, peripheral arterial disease and atherotrombotic brain infarction in men and women $>$ or $=62$ years of age. Am J Cardiol 74: 64-65, 1994.

24. Agnelli G, Cimminiello C, Meneghetti G and Urbinati S: The Polyvascular Atherothrombosis Observational Survey (PATHOS) Investigators. Low ankle-brachial index predicts an adverse 1-year outcome after acute coronary and cerebrovascular events. J Thromb Haemost 4: 2599-2606, 2006.

25. Santo Signorelli S, Anzaldi M, Fiore V, Catanzaro S, Simili M, Torrisi B and Neri S: Study on unrecognized peripheral arterial disease (PAD) by ankle/brachial index and arterial comorbidity in Catania, Sicily, Italy. Angiology 61: 524-529, 2010.

26. Westermann J, Thiermann F, Gerstetner L, Tatzber F, Kozak I Bertsch T and Kruger C: Evaluation of a new simple and rapid enzyme-like-immunosorbent assay kit for neopterin determination. Clin Chem Lab Med 38: 345-353, 2000.

27. Avanzas P, Arroyo-Espliguerro R, Coxin-Sales J, ldama G, Pizzi C, Quiles J and Kaski JC: Markers of inflammation and multiple complex stenoses (pancoronary plaque vulnerability) in patients with non-ST segment elevation acute coronary syndrome. Heart 90: 847-852, 2004

28. Sugioka K, Naruko T, Hozumi T, Nakagawa M, Kitabayashi C, Ikura Y, Shirai N, Matsumura Y, Ehara S, Ujino K, Itoh A, Haze K, Becker AE, Yoshiyama M and Ueda M: Elevated levels of neopterin are associated with carotid plaques with complex morphology in patients with stable angina pectoris. Atherosclerosis 208: 524-530, 2010.

29. Weiss G, Fuchs D, Hausen A, Reibnegger G, Werner ER, Werner-Felmayer G, Semenitz E, Dierich MP and Wachter H: Neopterin modulates toxicity mediated by reactive oxygen and chloride species. FEBS Lett 321: 89-92, 1993.
30. Murr C, fuchs D, Gossler W, Hausen A, Reibnegger G, Werner ER, Werner-Felmayer G, Esterbauer H and Wachter H: Ehnancement of hydrogen peroxide induced luminol-dependent chemiluminescence by neopterin depends on the presence of iron chaltor complexes. FEBS Lett 338: 223-226, 1994.

31. Resnick HE, Linday RS, Mc Dermott MM, Deveraux RB, Jones KL, Fabsitz RR and Howard RR: Relationship between high and low ankle brachial index to all-cause and to cardiovascular disease mortality: the Strong Heart Study. Circulation 109: 733-739, 2004.

32. Fiotti N, Giansante C, Ponte E, Delbello C, Calabrese S, Zacchi T, Dobrina A and Guarnieri G: Atherosclerosis and inflammation. Patterns of cytokine regulation in patients with peripheral arterial disease. Atherosclerosis 145: 51-60, 1999.

33. Brevetti G, Silvestro A, Di Giacomo S, Bucur R, Di Donato A, Schiano V and Scopacasa F: Endothelial dysfunction in peripheral arterial disease is related to increase in plasma markers of inflammation and severity of peripheral circulatory impairment but not to classic risk factors and atherosclerotic burden. J Vasc Surg 38: 374-379, 2003.

34. Schnabel RB, Schulz A, Messow CM, Lubos E, Wild PS, Zeller T, Sinning CR, Rupprecht HJ, Bickel C, Peetz D, Cambien F, Kempf T, Wollert KC, Benjamin EJ, Lackner KJ, Münzel TF, Tiret L, Vasan RS and Blankenberg S: Multiple marker approach to risk stratification in patients with stable coronary artery disease. Eur Heart J 31: 3024-3031, 2010

35. De Rosa S, Cirillo P, Pacileo M, Petrillo G, D'Ascoli GL, Maresca F, Ziviello F and Chiariello M: Neopterin: from forgotten biomarker to leading actor in cardiovascular pathophysiology. Curr Vasc Pharmacol 9: 188-199, 2011

36. Signorelli SS, Malaponte G, Libra M, Di Pino L, Celotta G, Bevelacqua V, Petrina $M$, Nicotra GS, Indelicato $M$, Navolanic PM, Pennini G and Mazzarino MC: Plasma levels and zymographic activities of matrix metalloproteinases 2 and 9 in type II diabetics with peripheral arterial disease. Vasc Med 10: $1-6,2005$.

37. Libra M, Signorelli SS, Bevelacqua Y, Navolanic PM, Bevelacqua V, Polesel J, Talamini R, Stivala F, Mazzarino MC and Malaponte G: Analysis of G(-174)C IL-6 polymorphism and plasma concentrations of inflammatory markers in patients with type 2 diabetes and peripheral arterial disease. J Clin Pathol 59: 211-215, 2006.

38. Signorelli SS, Anzaldi M and Fiore V: Inflammation in peripheral arterial disease (PAD). Curr Pharm Des 18: 4350-4357, 2012. 